\title{
Entrepreneurship Education at Tertiary Education Level: Implication to Historical Studies
}

\author{
Salahu Mohammed Lawal \\ Department of History and Archaeology \\ Ibrahim Badamasi Babangida University \\ Lapai, Niger state, Nigeria \\ Tel: 08028796952,07030235252
}

E-mail: salahumohammedlawal@yahoo.com \& salahumohammedlawal@rocketmail.com

Received: 020-04- 2013

doi:10.7575/aiac.ijels.v.1n.1p.33
Accepted: 01-06- 2013

Published: 01-07- 2013

\begin{abstract}
Nigeria is richly endowed with both human and material resources that when well utilized can make her one of the richest and developed nation in the world. But poor utilization of the resources, corruption and dwindling fortune in her education system made her among the first twenty five poorest nations in the world. Similarly, report shows that $26 \%$ of the employable population remained unemployed. This called for the need for entrepreneurship education most especially at tertiary level where high level manpower is supposed to be trained. It is on this premise that the paper attempts to examine entrepreneurship education and its implication to history students and graduates.
\end{abstract}

\section{Introduction}

Western education or formal education was introduced into Nigeria through Christian Missionaries activities in the mid $-19^{\text {th }}$ century. Much later in the $20^{\text {th }}$ century, the British colonial government reluctantly began to participate in the provision of western education. The colonial government involvement was due to the growing need of human capital to meet colonial exigencies and in response to criticism from the early nationalists. Despite this funding and provision of education was limited to secondary school level and unevenly provided across the country. These notwithstanding, provision of education facilities and accessibility since then has been on increase.

However, element of higher/tertiary education only began in 1932 when Government Survey School, Lagos, established in 1908 metamorphosed into Yaba Higher College (Ezugon, 2010). University education began in 1948 with the opening of University College, Ibadan. As Nigeria was preparing for independence, Ashby Commission was inaugurated to look into the future manpower needs of the nation. The Commission's report led to the establishment of University of Nigeria, Nsuka, University of Lagos, University of Ife (now Obafemi Awolowo University), Ahmadu Bello University, Zaria and the University College Ibadan became an autonomous institution as University of Ibadan. Since then, Nigeria has witnessed increment in the establishment and provision of tertiary education. In summary Nigeria has a total of 103 Universities, 123 Polytechnics, 101 Colleges of Education and a sizeable number of other degree and sub-degree awarding institutions (JAMB, 2011).

The growth in the provision of tertiary education could be linked to the continuous quest for higher education which is seen as the basis of economic empowerment and social mobility (Salahu, 2011). Economic empowerment and social mobility of an individual and indeed development of a nation is hinged on accessibility and quality of education that is made available. Hence Tony Blair (2006) in Mahadi (2008) said

Success will go to those countries which are swift complain, open and willing to change. The task of modern government is to ensure that our countries can rise to this challenge. More importantly than ever, they need sustained investment in science education and lifelong learning to make the most of the skills and talents of all their people to create a true knowledge economy.

This made Federal Government to describe education as an instrument 'per excellence' for effecting national development, hence continuous investment in the sector. The continuous investment in tertiary education by the government and the people is based on the expected goal of higher education to develop intellectual capacity, develop values for the survival of individual, manpower training, provide enabling and conducive environment as well as to acquire both physical and intellectual skills that will enable individuals to be self reliant and useful member of the society (National Policy on Education, NPE, 2004).

However, the present realities of high rate of unemployed graduates of tertiary education and its attendant social vices has put to test the description of education as an instrument per excellence and education for self reliance. This become more worrisome considering Nigeria's' strategic location along the coast, her landmass and natural resources therein 
that included rich or fertile vegetal cover, watered by a fairly well distributed rainfall and drainage system. The nation is also blessed with a variety of mineral resources that include crude oil, gas, limestone, tin, columbine, kaolin, gold, silver, coal, zinc, iron ore, bitumen among others (Irokwu, 1989, Salahu, 2008). The nation also has over 140million people (NPC, 2006). With these potentialities in human and material resources, Nigeria was expected to develop into a great nation that would be a source of pride to its citizens and well wishers. Unfortunately, Nigeria is plagued with high rate of poverty, corruption and unemployment among other problems despite these potentialities. Statistics shows that incidence of poverty and poverty rate in Nigeria has been on increased from $27 \%$ in 1980 to over $60 \%$ in 1990 s and above $70 \%$ since the turn of new century (Abdulkadir, 2010). In a similar note unemployment rate has been on increase most especially since the last two decades. It is reported that Nigeria unemployment level has reached an alarming level of $40.5 \%$ of the population of employable person (Shaibu, 2012).

The above situation has led to a number of questions regarding the nature, character, and quality, relevance of curricula, organization and management of tertiary education in Nigeria. These challenges which may include among others the following

$$
\begin{aligned}
& \text { - Question of relevance of the curricula } \\
& \text { - Question of functionality of the education system } \\
& \text { - Declining of quality and accessibility to formal education } \\
& \text { - Unemployable or learning on the job of the graduate. }
\end{aligned}
$$

These have led to different reform initiatives to address the teething problems to meet the needs of the recipient and the society and above all of global practices. As part of reform initiatives and strategies that of recent entrepreneurship education is being introduced and called for its inclusion in all program of our education system.

\section{Tertiary education and introduction of entrepreneurship Education: The emergent issues.}

As stated earlier, element of tertiary education began in Nigeria with the founding of Yaba Higher College in 1932. Since then more of such institutions have been established either by government, corporate organizations and individuals. Tertiary education according to Indabawa (2003) refers to all educational institutions offering post secondary school certificate, diploma and degree that include Universities, Colleges of Education, Polytechnics and research institutions. Adeyanju (2010) descried education at this level as education that enable the individual to acquire knowledge, skills and attitude that enables him fit into the national workforce efficiently. This made tertiary institutions of learning as where individuals realized their dreams in career choice through specialization in training and skill acquisition while the nation develops as manpower needed are being met (Salahu, 2007). This is also in line with the general goals of tertiary education as stated in National Policy on Education (NPE) 2004, thus,

- Contribute to national development through high level relevant manpower training.

- Develop and inculcate proper values for the survival of the individual and society.

- Develop the intellectual capacity of individuals to understand and appreciate their local and external environment.

- Acquire both physical and intellectual skills which will enable individuals to be self reliant and useful members of the society.

- $\quad$ Promote and encourage scholarship and community service

- $\quad$ Forge and cement national unity and

- Promote national and international understanding and interaction.

From the goals stated above, tertiary education has the mandate through teaching, research, dissemination of information and community services of producing conscious individuals with patriotic zeal and sense of national unity, producing individuals armed with intellectual capability, skills and necessary information to be self reliant, creator of wealth and even employer of labour, rather than being a burden on the society roaming the streets seeking for white collar jobs that are not available.

These supposedly highly trained individuals from the frustration of job seeking ended up becoming nuisance to the society through their activities. Many of them formed, organized or lead the resurgence of ethnic nationalities and militia groups, political thugs, kidnappers and academic machineries that perpetrate examination malpractices at the socalled miracle centers. These they did in an effort to earn a living. The question then is, of what relevant is their training and certificate they acquired?

The answer is not far from looking in-ward to our educational system and priority given to certificate as evidence of academic achievement. This could be attributed to the fact that either the individual recipient of tertiary education training failed to make use of the best opportunity by physically being there but spiritually and intellectually bereft of the training or, there is state of disequilibrium between labour market requirement and lack of essential employment skills by the graduates (Shaibu, 2012). This invariably means that the training received at the tertiary institutions has not adequately equipped them with desirable skills and competencies expected for wealth creation, self employment and even employer of labour. This made Tai Solarin in Mahadi (2008) to described Nigeria education as education which has produced and it is producing a snowball of unemployable young men and women in a country that is jammed with 
unemployment. Thus, one may conclude that nexus exist among the nation's economic situation, poverty and high rate of unemployment among the people which invariably could be linked to our education system.

Education enlightens an individual and enables him to acquire requisite knowledge and skills to understand his environment and the usefulness of the available resources before he can work to improve his wellbeing and contribute to the development of his society. But this depends on how the education is organized, who organized it and for what use. This accounts for the evolvement of NPE that began in 1969 in an effort to make education more relevant to the need of Nigerian people and the nation and move it away from the alien British transplant system (Akajagbor and Evve, 2008). Unfortunately since the official publication of the document in 1977, thirty five years later, the education system has produced individuals that lack national consciousness, lack of patriotism, lack of creativity, gross indolence, acute unemployed youth, poverty and corruption among others. These might have arisen from the dis - functionality of the system, hence the need for functional education to produce competent and capable labour that can be creative, resourceful and compete favorably any where he may find himself. This led to the call for modification in the tertiary education curriculla. Among such modification was the introduction of entrepreneurship education.

Entrepreneurship education is a new concept in education that put to use the learning methods, techniques and goals of vocational, technical and business education (VTBed) to the recipient. Abubakar in Mohammed (2010) sees entrepreneurship education as the study of techniques and related sciences and the acquisition of practical skills, attitudes, understanding and knowledge relating to occupation in various sector of economics and social life. Sani (2008) sees it as educational programme that prepares individual for the world of work as a teacher, office employee or be self reliant. It is also define as education that provides training experiences and skills that are suitable for entrepreneurship (Shake, Elakpobunor and Umar, 2010). Entrepreneurship education is therefore the entire process of providing the learner with necessary information, skills and competency desirable to be an entrepreneur, wealth creator and employable.

Entrepreneurship education therefore aimed at making the beneficiary to be employable, to be self employed or established a business outfit to create wealth and become employer of labour. These benefits of entrepreneurship education are what led to the call for its inclusion in the curriculum in an effort to make education functional to empower and develop the citizenry through provision of skills and knowledge that would prepare them for the world of works. This will further take them away from the streets, and indolence by making them creative and self reliance.

\section{History and Entrepreneurship Education.}

History is as old as man's existence on earth and formed a major component of non-formal education of every community in her stage of development. With the evolution of formal education through the advent of letters and writing it became one of the disciplines taught and learnt in Greece, Rome, Arab world including Egypt.

The formal teaching of history in Nigeria at schools began through imperial activities. Beginning from the establishment of Church Missionary Society Grammer School, Lagos in 1859 could improve through the colonial period and to 1980 s history feature prominently in the curricula. History thus comes to be taken at school certificate levels by most students. With the establishment of University College Ibadan, in 1948 department of history as one of the foundation courses lacks no students. Subsequently, when more universities were established history as a course was taught as many students enroll for it. This may not be unconnected with the training and career prospect of the course as recommended by the visitation panel report to University College Ibadan in 1952 on the need to offer honour degree in history;

Preparation not only for students who become specialist teachers in training college and schools, but also for students who would later enter political life, the administrative and other government services, the churches, journalism, broadcasting, commercial and industrial work and many other field of public life (Olisa in Lawal and Murtala, 2006).

True to the above recommendation graduates of history lack no jobs as many of them were sought for in the 1960s, 1970s and early 1980s. Many of them came to occupy commanding positions in academics, politics, administration and other services. For instance Prof. Okon Uya as a diplomat, Prof A.I. Asiwaju and B.M Barkindo at Boundary Commission, Prof Saad Abubakar as an Ambassador, Dr. J. Eborime at National Museum and Monuments and others in different fields of human endeavor.

The training graduates of history received and their output at their various fields of calling met the expectation of employers of labour and objectives of higher education of producing high level relevant manpower.

However from 1980s due to general economic down tune graduates of history and humanities began to face challenges of relevance. As the rate of unemployment increases our educational system came under scrutiny. This got to a stage when the then Federal Minister of Students Affairs in the Second Republic, Alhaji Bilyaminu Usman (1983) said.

The country now needs technological and result oriented education to prepare for the future. America and Russia did not go to the moon by studying history, philosophy, English language, but did so by encouraging technological growth.

Truly, history does not teach basic practical skill or vocational training as in applied sciences, technology or vocational courses. This made many see history as limiting itself to the past of man based on facts and evidences that lack practical for todays world. But the training received in searching and questioning of source and evidence was meant to provoke, promote and guide thought which will translate to efficient management of time and materials. This made historians to 
always excel and find their fortune when it comes to management of human and material resources for self fulfillment and societal development.

No doubt, many students keep distance from the discipline as quite a number of history graduates form a sizeable army of graduates roaming the streets searching for employment.

This could be attributed to either one or combination of the following:

- Government policy of favoring science and technology:

- The poor state of Nigeria economy that forced many to go for the so-called lucrative courses.

Misplace of value and low morality in the society and

Lack of creativity, initiative and above all indolence among the graduates.

From the above, history teaching and training methods provided to students at tertiary level equipped them with desirable knowledge, information and skills to be gainfully employed or self employed. Then, where does entrepreneurship education fits into history curriculum? This we shall discuss as implication.

Entrepreneurship education aimed at orientating individuals in to the world of work, history being a discipline that provides individual with desirable knowledge, information, skills and competencies required for wealth creation and self employment could be married together to better the lot of the students. Thus, entrepreneurship education can be integrated into history curriculum. This could be done through the teaching of the following with the aim to,

Expose students to economic potentials in Nigeria.

Instill spirit of accountability and efficient resource management

Promote creativity, personal initiative and self reliance

Offer training to improve individual's proficiency especially in relation to the present or future occupation.

Have an intelligent understanding of the increasing complexity of society to provide the desired change from dependence to independence and job creator as an entrepreneur (Ibrahim, 2010).

Expose students to different business ventures.

When integrated into history curriculum, it should be taught at final year of study cutting across the two semesters. In addition it should also be made a core course under general studies unit at the third and fourth or final year of study.

\section{Conclusion}

This paper has examined entrepreneurship education at tertiary education level with implication to historical studies. The paper identified that the growing rate of unemployment and attendant social vices among graduates of tertiary education was responsible for the need for entrepreneurship education. This stem from the belief that after about thirty five years of evolution of an indigenous educational policy, to make education meet the needs of the society, a state of disequilibrium was observed between education system and the labour employer requirement. Similarly, History that does not teach practical skills or gives vocational training considering the state of Nigeria economic and competency needed for survival the integration of entrepreneurship education into its curriculum become necessary to give bite to her training.

To this end in addition to what was highlighted in the paper, graduates of tertiary education during their National Youth Service year orientation camp be given further training in entrepreneurship education. Government should liberalize access to loans/finance by the end of the services year to enable them set up a small business outfit.

\section{References}

A Mahadi, Education and the Crises of Development in Nigeria (2008) A.S. Okegbile. S. A. E. Apare, E. O. Ogungbe, N. S. Taller and M. H. Moh'd (eds) Education and Development in North Nigeria Lapai F. E. A.

A.U. Aksjsgbor and A. D. Evve (2008) Education and the Challenges on the Nigerian Economy' Nigeria Journal of Teacher Education and Teaching V. 2. No. 2

A.U. Mohammed (2010) Enhancing Technical and Vocational Education Training (TVET) for self - Reliance in Nigeria. Niger Journal of Technology Education (NIJOTECH) Vol. 1. Pp. 123 - 127.

Alhaji Bilyaminu Usman, Nigerian Statement, $29^{\text {th }}$ November, 1983.

I. Ibrahim (2010) Achieving Self Reliance Through Business Education Nigeria Journal of Technical Education (NIJOTECH) Vol.1.

Federal Republic of Nigeria (2004) National Policy on Education.

I. Sani (2010) Entrepreneurship Education and the Secondary School Business Curriculum, N. S. Talla etal, Education for Sustainable Development in Nigeria Pp. $427-436$

JAMB, 2011 Brochure.

J. O. Irok (1989) Nigeria. The Case for a Better Society. Enugu. Fourth Dimension. 
J. S. Shaibu (2012) Entrepreneurial and Functional Education: A Tonic for the Attainment of Vision 20:2020 Multidisciplinary Journal of Research and Development 1 (2) Pp. 73 - 77

M L. Salahu (2007 Developing New Nigeria and the Challenges of General Studies in Tertiary Institution. A Historical Perspective in Journal of Vocational Education Kontagora Vol. 6. No. 1 P. $23-31$

M. L. Salahu (2008) Issues and Challenges of Nigeria Development. A History Perspective. Journal of the National Association for Science Humanities and Education Research 6.3 Pp. 116 - 125

M. L. Salahu and A. Yusuf, (2006) Historical Studies for Sustainable Development in Nigeria. G. A. Ashituabe and I. A. Kolo (eds) Education for Sustainable Development in Nigeria. Minna. Peak Press Pp. 266 - 281 on the Nigerian Economy Nigeria Journal of Teacher Education and Teaching V. 2 No. 2.

M. S. Abdulkadir (2010) Structuring Poverty and Unemployment in Nigeria, 1986 - 2008. The Nigeria Journal of Economic History. No. 1 and 10. Pp. $170-182$

S. M. Lawal and R. A. Murtala (2006) Historical Studies and the Challenges of Career Prospects in the $21^{\text {st }}$ Century Nigeria. Farfaru Journal of Multi - Disciplinary Studies Pp. 519 - 526

T. C.Ezugoh (2010). The Role of Nigeria Technical Education Institutions in Capacity and National Building N. S. Talle A.E. Apara, M. H. Moh'd and E.O. Ogungbe (eds) Education

T. K. Adeyanju (2010 Education for Nation - Building and Sustainable Development in Nigeria, N. S. Tallah et al, (eds) Education for Sustainable Development 